\title{
DAYA DUKUNG BAHAN KERING, PROTEIN KASAR DAN TOTAL DIGESTIBLE NUTRIEN LIMBAH TANAMAN PANGAN SEBAGAI PAKAN RUMINANSIA DI KECAMATAN TALAWAAN KABUPATEN MINAHASA UTARA
}

\author{
Adi Jonathan Ismael, Ch. L. Kaunang, K. Maaruf*, M. Waani \\ Fakultas Peternakan Universitas Sam Ratulangi Manado, 95115
}

\begin{abstract}
ABSTRAK
Penelitian yang bertujuan untuk mengetahui daya dukung nutrien limbah tanaman pangan sebagai pakan ruminansia telah dilaksanakan pada tanggal 1 Maret 6 April 2017 di Kecamatan Talawaan Kabupaten Minahasa Utara. Penelitian ini menggunaan metode deskriptif analisis. Data yang dikumpulkan meliputi data sekunder yang bersumber dari kantor Balai Pertanian Perikanan Peternakan dan Kehutanan (BP3K) Kecamatan Talawaan dan badan Pusat Statistik (BPS) Kabupaten Minahasa Utara. Parameter yang diamati adalah daya dukung limbah tanaman pangan (DDLTP) dan indeks daya dukung limbah tanaman pangan (IDDLTP) dari bahan kering $(\mathrm{BK})$, protein kasar $(\mathrm{PK})$ dan total nutrient dapat dicerna (TDN). Hasil penelitian menunjukkan bahwa daya dukung BK, PK dan TDN limbah tanaman pangan masing-masing sebesar $9664 \mathrm{ST}$, 5240 ST dan 8090 ST. IDDLTP (BK, PK, TDN) menunjukkan tingkat yang aman (>2) yakni berturut-turut dengan nilai 13.09 , 7.10, dan 10.96. Berdasarkan hasil penelitian ini disimpulkan bahwa dengan daya dukung sebesar 9664 ST (BK), 5240 ST (PK) dan 8090 ST (TDN) maka di wilayah Kecamatan Talawaan Minahasa Utara masih dapat ditambah pemeliharaan ternak ruminansia berturut-turut sebanyak 8926 ST, 4502 ST dan 7351,6 ST untuk BK, PK dan TDN dengan indeks daya dukung pada tingkat aman $(>2)$.
\end{abstract}

*Korespondensi (Corresponding author): Email: kartinimaaruf@yahoo.co.id
Kata Kunci: Limbah tanaman pangan, daya dukung nutrien, indeks daya dukung, ternak ruminansia

\section{ABSTRACT}

CARRYING CAPACITY OF DRY MATTER, CRUDE PROTEIN AND TOTAL NUTRIENT DIGESTIBILITY OF CROP WASTE AS RUMINANT FEED IN TALAWAAN SUB-DISTRICT OF NORTHERN MINAHASA. A research evaluating nutrient carrying capacity of crop residues as ruminant feed had been conducted since $1^{\text {st }}$ March $-6^{\text {th }}$ April 2017 in District Talawaan North Minahasa Regency. Descriptive method of analysis was used. Secondary data were collected from Balai Pertanian Peternakan dan Perikanan dan Kehutanan in Talawaan district and Statistics Center Bureau (BPS) North Minahasa Regency. Parameters observed were crop residues carrying capacity and carrying capacity index of dry matter (DM), crude protein (CP) and total digestible nutrient (TDN). The results showed that carrying capacity of DM, CP and TDN were 9664 AU, 5240 AU and 8090 AU, respectively. Carrying capacity indexes were at safe levels (> 2) 13.09, 7.10, and 10.96 for DM, CP and TDN, respectively. It can be concluded that carrying capacity of DM (9664 AU), CP (5240 AU) and TDN (8090 AU) can provide nutrients for additional $8926 \mathrm{AU}$ 
(DM), 4502 AU (CP) and $7351 \mathrm{AU}(\mathrm{TDN})$ of ruminants in Talawaan District, North Minahasa Regency with carrying capacity index of $>2$.

Keywords: Food crop residues, nutrient carrying capacity, carrying capacity index, ruminant livestocks.

\section{PENDAHULUAN}

Indonesia merupakan negara yang sangat potensial untuk pengembangan dan pembudidayaan ternak ruminansia dilihat dari sumber daya alam serta sumber daya manusia yang dimiliki. Melihat kondisi sumber daya yang baik, usaha peternakan ruminansia untuk pemenuhan kebutuhan masyarakat akan produk peternakan seharusnya dapat terpenuhi.

Pemeliharaan ternak ruminansia tidak terlalu sulit karena pemberian pakan utama yang berupa hijauan. Beberapa peran dari ternak ruminansia diantaranya, sebagai sumber bahan makanan bagi masyarakat berupa daging, sumber pendapatan bagi rumah tangga di pedesaan, sumber tenaga kerja, penyedia lapangan kerja, tabungan dan sumber devisa yang potensil serta sumber pupuk organik untuk perbaikan kualitas tanah (Salendu dan Elly, 2012). Sarwono dan Ariyanto (2005) menyatakan bahwa sifat paling menonjol pada ruminansia adalah keperluan pakannya tidak bersaing dengan manusia. Bahan pakan ternak ruminansia dapat mengandalkan hijauan dan limbah pertanian yang tidak dikonsumsi oleh manusia. Ternak ruminansia dapat mencerna pakan berserat tinggi dan mengubahnya menjadi daging. Kemampuan itu menunjukan hewan ruminansia memiliki proses pencernaan yang khas. Pakan merupakan bahan makanan yang dapat dimakan dan tidak membahayakan bagi tubuh ternak. Pakan menyediakan nutrien yang penting untuk hidup, produksi, dan reproduksi (Nurlaha 2015).

Limbah tanaman pangan sebagai bahan pakan selalu dikaitkan dengan harga yang murah dan kualitas yang rendah, beberpa limbah tanaman pangan yang potensial sebagai pakan adalah jerami padi, jerami jagung, jerami kacang kedele, jerami kacang tanah, daun ubi jalar, daun singkong dan limbah pertanian lainya (Tanuwiria et al., 2006). Matulessy dan Kastanja (2013) menyatakan bahwa beberapa faktor yang menyebabkan peternak tidak memanfaatkan limbah tanaman pangan (jerami padi / jerami jagung / jerami ubi jalar) sebagai pakan adalah: a) umumnya petani membakar limbah tanaman pangan terutama jerami padi karena secepatnya akan dilakukan pengolahan tanah, b) 
limbah tanaman pangan bersifat kamba sehingga menyulitkan peternak untuk mengangkut dan umumnya lahan pertanian jauh dari pemukiman peternak sehingga membutuhkan biaya pengangkutan, c) tidak tersedianya tempat penyimpanan dan peternak tidak bersedia menyimpan limbah di sekitar rumah d) peternak menganggap bahwa ketersediaan hijauan di lahan pekarangan, kebun, sawah masih mencukupi.

Pemeliharaan ternak ruminansia di Kecamatan Talawaan sangat potensial karena ketersediaan hijauan dan limbah tanaman pangan sebagai pakan ruminansia melimpah serta lahan untuk pemeliharaan masih luas. Tujuan dari penelitian ini adalah untuk mengetahui daya dukung BK, PK dan TDN limbah tanaman pangan sebagai pakan ruminansia di Kecamatan Talawaan, Kabupaten Minahasa Utara.

\section{MATERI DAN METODE PENELITIAN}

\section{Waktu dan Lokasi Penelitian}

$$
\text { Penelitian dilaksanakan di }
$$

Kecamatan Talawaan - Minahasa Utara sejak tanggal 1 Maret sampai dengan 6 April 2017. Penentuan daerah penelitan dilakukan dengan metode purposive sampling dengan pertimbangan daerah tersebut adalah salah satu kecamatan di
Minahasa Utara yang mempunyai limbah tanaman pangan yang melimpah.

\section{Materi Penelitian}

Alat yang digunakan dalam penelitian ini adalah kamera sedangkan data yang digunakan adalah data sekunder.

\section{Metode Penelitian}

Metode yang digunakan adalah metode deskriptif analisis. Metode ini dilakukan dengan mengumpulkan data dari kantor Balai Pertanian Perikanan Peternakan dan Kehutanan (BP3K) Talawaan dan Badan Pusat Statistik (BPS) Minahasa Utara.

\section{Parameter yang ukur :}

Parameter yang diukur adalah: Daya dukung limbah tanaman pangan (DDLTP) dan Indeks daya dukung tanaman pangan (IDDTP) dari bahan kering (BK), protein kasar $(\mathrm{PK})$ dan total nutrient dapat dicerna (TDN) sesuai petunjuk Ditjen Peternakan dan Fapet UGM (1982) disitasi Fatmona (2007).

1. DDLTP :

a. DDLTP Bahan kering $(\mathrm{BK})=$

$$
\frac{\text { produksi bahan kering }}{\text { Kebutuhan BK( } \mathrm{kg} / \mathrm{ST} / \mathrm{Thn})}
$$

b. DDLTP Protein Kasar $(\mathrm{PK})=$

$$
\frac{\text { produksi protein kasar }}{\text { Kebutuhan BK }(\mathrm{kg} / \mathrm{ST} / \mathrm{Thn})}
$$

c. DDLTP TDN =

$$
\frac{\text { produksi TDN }}{\text { Kebutuhan BK }(\mathrm{kg} / \mathrm{ST} / \mathrm{Thn})}
$$

2. IDDLTP 
a. IDDLTP BK =

Total produksi BK $(\mathrm{kg})$

$\overline{\text { populasi }(S T) x \text { kebutuhan } B K\left(\frac{k g}{S T} / \text { thn }\right)}$

b. IDDLTP PK =

Total produksi $\mathrm{PK}(\mathrm{kg})$

$\overline{\text { populasi (ST) x kebutuhan BK }\left(\frac{\mathrm{kg}}{\mathrm{ST}} / \mathrm{thn}\right)}$

c. IDDLTP TDN =

Total produksi TDN $(\mathrm{kg})$

$\overline{\text { populasi }(S T) \text { x kebutuhan } B K\left(\frac{\mathrm{kg}}{\mathrm{ST}} / \mathrm{thn}\right)}$

\section{HASIL DAN PEMBAHASAN}

\section{Keadaan Umum Kecamatan Talawaan}

Kecamatan Talwaan mempunyai alam tropis yang relatif basah, berada di ketinggian \pm 100 meter dari atas permukaan laut, sebagian besar adalah dataran berombak dengan suhu udara rata-rata 22$29^{\circ} \mathrm{C}$, dan terdiri dari 12 desa dengan luas
$106,32 \mathrm{~km}^{2}$. Jumlah penduduk Kecamatan Talawaan pada tahun 2015 adalah 20.493 jiwa dan kepadatan penduduknya mencapai 197,2 jiwa $/ \mathrm{km}^{2}$ (BPS 2016). Tabel 5 menunjukkan jumlah penduduk di kecamatan Talawaan pada setiap desa. Tabel 5 menunjukkan desa yang memiliki luas wilayah paling besar di Kecamatan Talawaan adalah desa Winetin yaitu sebesar $\pm 19,40 \mathrm{~km}^{2}$, sedangkan desa yang luas wilayahnya paling kecil adalah Paniki Baru yang luasnya $\pm 0,10 \mathrm{~km}^{2}$. Jika dilihat dari kependudukannya, jumlah penduduk terbanyak adalah desa Mapanget yang jumlah penduduknya sebanyak 6.929 jiwa dimana luas daerahnya lebih kecil dari desa Winetin sedangkan desa Tumbohon yang memiliki kependudukan yang paling sedikit yaitu 525 jiwa dengan luas wilayah lebih besar dari desa Paniki Baru yaitu 16,94 km.

Tabel 5. Jumlah Penduduk Dan Luas Wilayah Kecamatan Talawaan tahun 2015.

\begin{tabular}{lrc}
\hline Desa & Jumlah Penduduk & Luas Wilayah $\left(\mathrm{Km}^{2}\right)$ \\
\hline Talawaan & 3.171 jiwa & 18,58 \\
Tumbohon & 525 jiwa & 16,94 \\
Kolongan & 1.501 jiwa & 1,40 \\
Mapanget & 6.929 jiwa & 7,50 \\
Winetin & 556 jiwa & 19,40 \\
Patokaan & 593 jiwa & 7,50 \\
Wusa & 1.146 jiwa & 10,30 \\
Warisa & 817 jiwa & 8,60 \\
Teep Warisa & 601 jiwa & 6 \\
Paniki Atas & 2.320 jiwa & 6,30 \\
Warisa Kampung Baru & 684 jiwa & 4 \\
Paniki Baru & 1.650 jiwa & 0,10 \\
\hline Jumlah & 20.493 jiwa & 106,32
\end{tabular}

Sumber : Kecamatan Talawaan Dalam Angka 2016 


\section{Populasi Ternak Ruminansia}

Populasi ternak dapat menggambarkan kinerja pembangunan peternakan, kesesuaian ternak dengan kondisi wilayah, daya terima masyarakat dan minat masyarakat dalam pemeliharaan ternak tersebut. Di Kecamatan Talawaan hanya dua jenis ternak ruminansia yang ada dan dikembangkan oleh masyarakat sebagai tabungan maupun sebagai tenaga kerja dalam bidang pertanian yaitu ternak sapi dan kambing. Data populasi ternak yang diperoleh dalam satuan ekor disetarakan dalam satuan ternak (ST). Data populasi ternak dalam ST di Kecamatan Talawaan tercantum dalam Tabel 6 . Perhitungan populasi dari satuan ekor menjadi satuan ternak dilakukan dengan faktor perkalian yakni sapi 0.7 dan kambing 0.05 (Atmiyati, 2006). Tabel 6 menunjukkan bahwa populasi ternak sapi di Kecamatan Talawaan berjumlah 738,4 ST yang terdiri dari ternak jantan sebanyak 242,9 ST dan betina sebanyak 485,8 ST . Ternak kambing lebih sedikit dibandingkan dengan ternak sapi yakni 9,7 ST, yang terdiri dari jantan sebanyak 3,3 ST dan betina sebanyak 6,4 (ST). Masyarakat di Kecamatan Talawaan memelihara ternak sapi lebih banyak dibandingkan dengan ternak kambing karena pemeliharaan ternak sapi sangat membantu para petani-peternak dalam bidang pertanian sebagai tenaga kerja untuk membajak lahan pertanian dan sebagai alat pengangkut hasil pertanian. Salendu dan Elly (2012) menyatakan bahwa beberapa peran dari ternak ruminansia diantaranya, sebagai sumber bahan makanan bagi masyarakat berupa daging, sumber pendapatan bagi rumah tangga di pedesaan, sumber tenaga kerja, penyedia lapangan kerja, tabungan dan sumber devisa yang potensial serta sumber pupuk organik untuk perbaikan kualitas tanah.

\section{Produksi Limbah Tanaman Pangan}

Salah satu sumber pakan ternak ruminansia adalah limbah tanaman pangan baik dalam bentuk segar maupun kering. Produksi limbah tanaman pangan bargantung dari budidaya tanaman pangan.

Tabel 6. Data Populasi Ternak di Kecamatan Talawaan Tahun 2016

\begin{tabular}{llll}
\hline Jenis ternak & Jantan $(\mathrm{ST})$ & Betina $(\mathrm{ST})$ & Jumlah $(\mathrm{ST})$ \\
\hline Sapi & 242,9 & 485,8 & 728,7 \\
Kambing & 3,3 & 6,4 & 9,7 \\
\hline Total & 246,2 & 492,2 & 738,4 \\
\hline
\end{tabular}

Sumber : BP3K Kecamatan Talawaan 
Tabel 7. Ketersediaan Bebarapa Jenis Limbah Tanaman Pangan di Kecamatan Talawaan Pada Tahun 2016

\begin{tabular}{lcc}
\hline Komoditas Tanaman Pangan & $\begin{array}{c}\text { Luasan Panen } \\
(\mathrm{Ha})\end{array}$ & $\begin{array}{c}\text { Produksi Limbah Tanaman } \\
\text { Pangan (Ton BK/Tahun) }\end{array}$ \\
\hline Padi sawah & 1229 & 282,67 \\
Padi ladang & 175 & 40,25 \\
Jagung & 1944 & $21.189,6$ \\
Kedele & 393 & 420,51 \\
Kacang tanah & 35 & 50,4 \\
Ubi kayu & 10 & 50,5 \\
Ubi jalar & 10 & 12 \\
\hline Total & 3796 & $22.045,93$ ton BK
\end{tabular}

Sumber: BP3K Kecamatan Talawaan, 2016.

Pembangunan tegnologi budidaya tanaman pangan di Kecamatan Talawaan dapat dikatakan maju karena di Kecamatan Talawaan terdapat sarana dan prasarana yang tersedia guna membantu petani dalam berbudidaya tanaman pangan. Pemanfaatan jerami di Kecamatan Talawaan masih sangat kurang, jerami yang tersedia biasanya hanya dibiarkan dan dibakar saat dilakukan pengolahan lahan kembali. Hal ini disebabkan hanya sedikit petani yang memiliki ternak. Pemberian limbah tanaman pangan kepada ternak sebagai pakan hanya dilakukan sesekali oleh beberapa petani. Hal ini sangat disayangkan mengingat produksi limbah tanaman pangan yang banyak belum dimanfaatkan secara maksimal sebagai pakan oleh peternak. Untuk mengoptimalkan penggunaan limbah tanaman pangan yang tersedia sebagai pakan perlu adanya penambahan ternak dengan memperhitungkan daya dukung. Zailizar et al. (2011) menyatakan bahwa ternak ruminansia (sapi, kerbau, domba dan kambing) dapat memanfaatkan sisa-sisa hasil pertanian.

Adapun tanaman pangan yang di kembangkan adalah padi sawah, padi ladang, jagung, kedele, kacang tanah, ubi kayu, dan ubi jalar. Luas lahan tanaman pangan yang dipanen di Kecamatan Talawaan dapat dilihat pada Tabel 7. Total luas panen selama tahun 2016 adalah 3796 Ha. Jagung merupakan komoditas dengan luas panen terbesar yaitu 1944 ha sedangkan ubi kayu dan ubi jalar mempunyai luas panen terkecil yakni masing-masing 10 ha. Semakin besar luas lahan panen tanaman pangan maka semakin tinggi produksi limbah tanaman pangan. Dari data yang terdapat dalam Tabel 7 dapat dilihat bahwa besarnya luas lahan produksi tanaman pangan di Kecamatan Talawaan 
yakni 3796 ha. Berdasarkan rumus Nell dan Rollinson (1974) disitasi Arifin dan Riszqina (2016) diperoleh total ketersediaan limbah tanaman pangan sebanyak 22.045,93 ton BK/tahun. Produksi jerami jagung adalah yang terbesar yaitu 21.189,6 ton BK diikuti dengan produksi jerami kedele sebesar 420,51 ton BK sedangkan produksi jerami ubi jalar adalah yang terkecil yaitu 12 ton BK.

\section{Daya Dukung Limbah Tanaman Pangan.}

Daya dukung merupakan kemampuan suatu wilayah dalam menunjang penyediaan pakan ternak yang dihasilkan dari suatu wilayah administratif. Suatu wilayah dikatakan mampu apabila pakan ternak yang tersedia di wilayah tersebut lebih besar dari kebutuhan ternak (Atmiyati, 2006).

a. Daya dukung BK limbah tanaman pangan

Hasil perhitungan daya dukung limbah tanaman pangan di Kecamatan
Talawaan sebesar 9664 (Tabel 8) artinya dengan produksi limbah tanaman pangan sebesar 22.045.930 kg BK/ Tahun mampu untuk memenuhi kebutuhan BK ternak ruminansia sebanyak 9664 ST. Populasi ternak ruminansia di Kecamatan Talawaan hanya sebesar 738.4 ST (Tabel 6) sehingga perlu penambahan ternak ruminansia sebanyak 8926 ST agar pemanfaatan limbah tanaman pangan dapat optimal. Menurut Kearl (1982) disitasi Nanda et al. (2014) menyatakan bahwa konsumsi BK pakan dipengaruhi oleh bobot hidup ternak. Semakin tinggi bobot hidup ternak, konsumsi BK pakan semakin tinggi pula. Penelitian daya dukung BK juga dilakukan oleh Tiwow (2016) yang melaporkan bahwa ketersediaan pakan ruminansia di Pakakaan mencapai 135.484 Ton BK/tahun. Ketersediaan sejumlah itu dapat memenuhi kebutuhan 118846 ST sedangkan jumlah ternak diwilayah tersebut sebanyak 8046 ST. Dengan demikian populasi ternak dapat ditingkatkan sebanyak 108740 ST.

Tabel 8. Daya dukung limbah tanaman pangan (DDLTP) di Kecamatan Talawaan

\begin{tabular}{lccc}
\hline Nutrien & $\begin{array}{c}\text { Produksi Limbah } \\
\text { Tanaman Pangan } \\
\text { kg/tahun }\end{array}$ & $\begin{array}{c}\text { Kebutuhan Nutrien } \\
\text { kg/ST/thun }\end{array}$ & $\begin{array}{c}\text { DDLTP } \\
(\mathrm{ST})\end{array}$ \\
\hline BK & 22.045 .930 & 2281,25 & 9664 \\
PK & 1.262 .404 & 240,9 & 5240 \\
TDN & $12.697 .216,31$ & 1569,5 & 8090 \\
\hline
\end{tabular}


b. Daya dukung PK limbah tanaman pangan

Hasil penelitian daya dukung PK limbah tanaman pangan di Kecamatan Talawaan yaitu sebesar 5240 (Tabel 8) artinya dengan produksi PK limbah tanaman pangan di Kecamatan Talawaan sebesar $1.262 .404 \mathrm{~kg} \mathrm{PK} / \mathrm{tahun}$, mampu untuk memenuhi kebutuhan PK ternak ruminansia sebanyak 5240 ST. Populasi ternak ruminansia di kecamatan Talawaan hanya sebesar 738.4 ST (Tabel 6) sehingga perlu penambahan ternak ruminansia sebanyak 4502 ST agar pemanfaatan limbah tanaman pangan dapat optimal. Menurut Kearel (1982) dan Bondi (1987) yang disitasi Imran et al. (2012) bahwa ketersediaan protein dalam ransum sapi sangat penting karena protein merupakan komponen utama organ tubuh, enzim, zat pengangkut hormon dan sebagainya. Penelitian daya dukung PK juga dilakukan oleh Fatmona (2007) yang melaporkan bahwa daya dukung PK pakan di Kabupaten Halmahera Barat mencapai 9.185.515,15 ST.

c. Daya dukung TDN limbah tanaman pangan

Pada Tabel 8 terlihat daya dukung TDN limbah tanaman pangan di Kecamatan Talawaan sebesar 8090 ST dengan ketersediaan limbah tanaman pangan sebesar 12.697.216,31 kg TDN/tahun. Populasi ternak ruminansia di kecamatan
Talawaan hanya sebesar 738,4 ST (Tabel 6) sehingga perlu penambahan ternak ruminansia sebanyak 7351,6 ST agar pemanfaatan limbah tanaman pangan dapat optimal. Total digestible nutrien (TDN) adalah total energi zat makanan pada ternak yang disetarakan dengan energi dari karbohidrat yang dapat diperoleh dengan uji biologis maupun dengan perhitungan menggunakan data hasil analisis proksimat. Penelitian daya dukung TDN juga dilakukan oleh Fatmona (2007) yang melaporkan bahwa daya dukung TDN pakan di Kabupaten Halmahera Barat mencapai 3.593.297,67 ST.

\section{Indeks Daya Dukung Limbah Tanaman Pangan}

Indeks daya dukung BK, PK dan TDN limbah tanaman pangan sebagai pakan ruminansia di Kecamatan Talawaan dapat dilihat dalam Tabel 9Hasil perhitungan IDDLTP di Kecamatan Talawaan berdasarkan BK, PK, dan TDN masing-masing menunjukkan tingkat keamanan yang aman (>2) yakni dengan nilai berturut-turut 13,$09 ; 7,10$ dan 10,96 . Tingginya IDDLTP disebabkan populasi ternak ruminansia di Kecamatan Talawaan sedikit sehingga ketersediaan nutrien (BK, PK dan TDN) melebihi kebutuhan ternak. Atmiyati (2006) menyatakan bahwa indeks daya dukung mencerminkan tingkat 
Tabel 9 menunjukkan indeks daya dukung limbah tanaman pangan (IDDLTP) di kecamatan Talawaan.

\begin{tabular}{lcccc}
\hline Nutrien & $\begin{array}{c}\text { Produksi Limbah } \\
\text { Tanaman Pangan } \\
\text { kg/tahun }\end{array}$ & $\begin{array}{c}\text { Populasi } \\
\text { (ST) }\end{array}$ & Kebutuhan & IDDLTP \\
\hline BK & 2.204 .930 & 738,4 & 1.684 .475 & 13,09 \\
PK & 1.262 .404 & 738,4 & $177.880,6$ & 7,10 \\
TDN & $12.697 .216,31$ & 738,4 & $1.158 .918,8$ & 10,96 \\
\hline
\end{tabular}

keamanan pakan pada suatu wilayah, untuk mendukung kehidupan ternak yang berada di atasnya. Hasil penelitian Tiwow (2016) menunjukan indeks daya dukung rumput alami dan jerami di Kawasan Pakakaan Kabupaten Minahasa adalah 12.

\section{KESIMPULAN}

Berdasarkan hasil penelitian ini disimpulkan bahwa berdasarkan daya dukung sebesar 9664 ST (BK), 5240 ST (PK) dan 8090 ST (TDN) maka di wilayah Kecamatan Talawaan masih dapat ditambah pemeliharaan ternak ruminansia berturut-turut sebanyak 8926 ST, 4502 ST dan 7351,6 ST untuk BK, PK dan TDN dengan indeks daya dukung pada tingkat $\operatorname{aman}(>2)$.

\section{DAFTAR PUSTAKA}

Arifin, M.Z. dan Riszqina. 2016. Analisis potensi pengembangan sapi potong melalui pendekatan lahan dan sumber daya manusia di Kecamatan Galis Kabupaten
Pamekasan. Madura . Jurnal IlmuIlmu Peternakan Maduranch Vol.1 (1): $1-12$

Atmiyati. 2006. Daya dukung hijauan pakan terhadap pengembangan ternak di kabupaten Sumbas. Balai Penelitian Ternak. Bogor

Balai Pertanian Peternakan Perikanan dan Kehutanan (BP3K). 2016. Kecamatan Talawaan.

Badan Pusat Statistik (BPS). 2016. Kecamatan Dalam Angka 2016. Minahasa Utara

Fatmona, S. 2007. Pengembangan Peternakan Sapi Potong Yang Diintegrasikan Dengan Perkebunan Kelapa Di Kabupaten Halmahera Barat Provinsi Maluku Utara. Tesis. Program Studi Ilmu Ternak IPB. Bogor

Imran., S.P.S. Budhi, N. Ngadiyono, Dahlanuddin. 2012. Pertumbuhan pedet sapi bali yang diberi rumput lapangan dan disuplementasi daun turi (Sesbania Grandiflora). Yogyakarta. Agrinimal Vol.2 (2): 55-60

Matulessy, N.D. dan A. Y. Kastanja. 2013. Potensi hijauan bahan pakan ternak di Kecamatan Tobelo Kabupaten Halmahera Utara. 
Jurnal Agroforestry VIII (4): 287293

Nanda, D.D., A. Purnomoadi., L.K. Nuswantara. 2014. Penampilan produksi sapi bali yang diberi pakan dengan berbagai level pelepah sawit. Agromedia, Vol. 32 (2): 54-63.

Nurlaha, L. Abdulah, D. Diapari. 2015. Kecukupan asupan nutrien asal hijauan pakan kambing PE didesa Totallang Kolaka Utara. Sulawesi Tenggara. Jurnal Ilmu Pertanian Indonesia (JIPI) Vol.2(1); 18-25

Salendu, A.H.S dan Femi H. Elly . 2012. Pemanfaatan lahan dibawa pohon kelapa untuk hijauan pakan sapi di Sulawesi Utara. Fakultas Peternakan Unsrat Manado. Jurnal Ilmu Tumbuhan Pakan Tropik Vol.2(1): 21-25

Sarwono, B. dan N.B. Ariyanto. 2005. Penggemukan sapi potong secara cepat. PT Penebar Swadaya. Jakarta

Tanuwiria, U.H., A.Yulianti, N. Mayasari. 2006. Potensi pakan asal limbah tanaman pangan dan daya dukungnya terhadap populasi ternak ruminansia di wilayah Sumedang. Jurnal Ilmu Ternak Vol.6 (2): $112-120$

Tiwow. H. A. L., V. V. J. Panelewen, A.Dp. Mirah. 2016. Analisis Potensi Daya Dukung Lahan Untuk Pengembangan Sapi Potong Di Kawasan Pakakaan Kabupaten Minahasa. Universitas Sam Ratulangi Manado. Jurnal Zootek Vol. 36 (2): 476 - 486.

Zailzar, L., Suyanto, A. Yani. 2011. Peningkatan kuanlitas dan ketersediaan pakan untuk mengatasi kesulitan dimusim kemarau pada kelompok peternak sapi perah. Fakultas Pertanian dan Peternakan UMM. Jurnal Dedikasi. Vol 8: 15-28 . 